\title{
Molecular Properties, Bioactivity Scores, and Toxicity Predictions of the Phytoconstituents Present in Bauhinia Acuminata
}

\author{
Neelima Kudumula ${ }^{1 *}$, Noota Divya ${ }^{2}$, Nagamalla Sravika ${ }^{3}$, Saketha Priya $^{4}$, Pachava Anusha ${ }^{5}$, \\ Mudavath Sai Jyotsna'. \\ 1*Associate Professor, Department of Chemistry, Sarojini Naidu Vanita Pharmacy Mahavidyalaya, \\ Tarnaka, Osmania University, Hyderabad, Telangana, India. \\ ${ }^{2-6}$ B.Pharmacy Students, Sarojini Naidu Vanita Pharmacy Mahavidyalaya, Tarnaka, Hyderabad, Telangana, \\ India.
}

\begin{abstract}
:
To develop the herbal drug with the least side effects, there are superior opportunities to discover the medicinal and other biological properties. Natural products serve as sources of beneficial chemical molecules. For this study, Bauhinia acuminata an important medicinal plant of the Indian subcontinent that belongs to the family Fabaceae was chosen. The plant is well known for its precautionary action in tuberculosis. It has been established to possess some pharmacological activities such as membranes Stabilizing activity1, antibacterial2, anti-nociceptive3, thrombolytic activity4, antioxidant5, anthelmintic6, anti-diarrheal7, Hepato-protective 8.

Phytoconstituents present in Bauhinia acuminata obey Lipinski's rule (MiLog P <5) except Kaempferol-3glucoside indicated their drug-likeness property. Rhoeagenine, 9, 12, 15-octadecatrienoic acid, and 9, 12octadecadienoic acid are the phytoconstituents showing all types of binding with all types of receptors binding except Kinase inhibitor activity.

Rhoeagenine, Alpha humulene, 9, 12, 15-octadecatrienoic acid, 9, 12-octadecadienoic acid, Alpha muurolol, Beta-sitosterol, Kaempferol-3-glucoside are the phytoconstituents that are free from any type of toxicity. The accurate prediction scores can be used as monographs by researchers and scientists for the development of potential Semisynthetic and synthetic drugs for multifarious usage.
\end{abstract}

Keywords: Bauhinia acuminata, Molinspiration software, Osiris software, Toxicity profile, Phytoconstituents, Bioactivity score.

\section{Introduction:}

The prehistoric people have great consciousness of the tradition of medicinal plants as herbal medicines. In the world, more than $80 \%$ of the living in minor developed countries reveals on customary medicine and humans are dependent on herbs for their basic requirements such as foodstuffs, clothing, flavor, shelter, fragrance, and medicines (Divya and Mini, 2011 \& Manoj Kumar Mishra, 2016, Gurib-Fakim, 2006 and Brijesh \& Madhusudan, 2015). The Discovery of drugs in medicinal plants affords better and vital leads, besides diverse pharmacological activities such as cytotoxic, anti-diarrheal, antimicrobial, antiinflammatory, antioxidant, anthelmintic, anti-nociceptive, hemolytic activity. The plant is well known for its precautionary action in tuberculosis. As per the recommendations of Ayurveda Bauhinia acuminata is the one of important medicinal plants for the treatment of disorders. (Yi F et al, 2016) ${ }^{9}$.

Bauhinia acuminata belonging to the family of Fabaceae is an evergreen large shrub grows in the areas of Southeast Asia such as Malaysia, Indonesia or Philippines. For conventional drugs, bark, leaves, stem, blooms, and Roots have been utilized.

Chemical constituents present in Bauhinia acuminata leaves are palmitic acid, three phallic acid esters, gallic acid, and ursolic acid. The leaves and stems of B. acuminata have shown the presence of carbohydrate, saponins, phenolic compounds, flavonoids, oils, and fats, alkaloids, anthocyanoside, steroids, anthraquinone, 
terpenoids, resins, amino acid, sugars, and cardiac glycosides. In phytochemical screening, leaf oil identified 13 compounds in B. acuminata through GC-MS analysis are Quercetin, Neophytadiene, Rhoeagenine, Alpha humulene, Isoaromadendrene epoxide (Vasudevan et al.,2013), Butanedioic acid diethyl ester,9,12,15octadecatrienoic acid, Beta-ionone, 9,12-octadecadienoic acid, Alpha muurolol, Bauhinione, Beta-sitosterol, Kaempferol-3-glucoside. Phytochemical plant extracts when screened have shown the presence of saponin, alkaloid, cardiac glycosides, flavonoids, and tannin and steroid compounds (Dongray et al, 2016) ${ }^{10}$.

\section{Molinspiration}

\section{i) Lipinski's rule}

Lipinski's rule of five also known as Pfizer's rule of five or simply the Rule of five (RO5) is a rule of thumb to evaluate drug-likeness or determine if a chemical compound with a certain pharmacological or biological activity has properties that would make it a likely orally active drug in humans. The rule was formulated by Christopher A. Lipinski in 1997.

The rule describes molecular properties important for a drug's pharmacokinetics in the human body, including their absorption, distribution, metabolism, and excretion ("ADME") Components of Lipinski's rule:

\section{ii) Lipinski's rule states}

- A molecular mass of fewer than 500 daltons.

- An octanal-water partition coefficient $\log \mathrm{P}$ not greater than 5 .

- Not more than 10 hydrogen bond acceptors (nitrogen or oxygen atoms).

- Not more than 5 hydrogen bond donors (nitrogen or oxygen atoms with one or more hydrogen atoms).

- No more than one violation.

\section{iii) Drug likeness score}

Molinspiration is web-based software which can be used to obtain parameters such as MiLog P, druglikeness scores, TPSA. MiLog P is calculated by the methodology developed by Molinspiration which is a sum of fragment-based contributions and correction factors. Good permeability across the cell membrane can be checked with MiLog $\mathrm{P}$ value. Log $\mathrm{P}$ or Partition coefficient is an important parameter used to measure molecular hydrophobicity in rational drug design. The hydrophilic/lipophilic nature of drug molecules affects drug absorption, bioavailability, drug-receptor interactions, as well as their toxicity. Based on a sum of fragment contributions of $\mathrm{O}$ and $\mathrm{N}$ - centered polar fragments Molecular Polar Surface Area TPSA is calculated. Total polar surface area (TPSA) is closely related to the hydrogen bonding potential of a molecule and is a very good predictor of drug transport properties such as intestinal absorption, bioavailability, blood-brain barrier penetration, etc. Based on group contributors, the calculation of volume were developed at Molinspiration The number of rotatable bonds measures molecular flexibility. It is a very good descriptor of the absorption and bioavailability of drugs. Molecular properties and structure features with respect to known drugs can be checked through drug-likeliness data of the molecule. MiLog $\mathrm{P}$ (partition coefficient), molecular weight, number of heavy atoms, number of hydrogen donors, number of hydrogen acceptors and number of violations, number of rotatable bonds, and volume ${ }^{11}$ are the parameters considered for calculating the drug-likeness scores.

\section{iv) Bioactivity score}

Bioactivity of the drug can be checked by calculating the activity score of GPCR ligand, ion channel modulator, nuclear receptor legend, a kinase inhibitor, protease inhibitor, enzyme inhibitor. Calculated drug-likeness score of each compound and compared with the specific activity of each compound, and the results were compared with standard drug. All the parameters were checked with the help of the software Molinspiration drug-likeness score online (www.molinspiration.com). The probability for the organic molecules is if the bioactivity score is $(>0)$, then it is active, if $(-5.0-0.0)$ then moderately active, if $(<-5.0)$ then inactive

\section{Materials And Methods \\ i) Materials:}

Phytochemical compounds present in Bauhinia acuminata like Quercetin, Neophytadiene, Rhoeagenine, Alpha humulene, Isoaromadendrene epoxide (Vasudevan et al.,2013), Butanedioic acid diethyl ester, 9,12,15-octadecatrienoic acid, Beta-ionone, 9,12-octadecadienoic acid, Alpha muurolol, Bauhinione, Beta- 
sitosterol, Kaempferol-3-glucoside which are listed in Table 1 were selected for Insilco prediction and the smile notations of used to generate the data.

\section{ii) Methods:}

Molinspiration Software: Structures of 13 phytochemical compounds selected for our work as given in Table 1 (reported in the literature resources) were drawn using online molinspiration for the calculation of molecular properties like MiLog P, Total polar surface area (TPSA), number of hydrogen bond donors and acceptors, molecular weight, number of atoms, number of rotatable bonds, etc., and bioactivity scores like GPCR ligands, kinase inhibitors, ion channel modulators, enzymes, and nuclear receptors. The molecular properties and bioactivity scores predicted by molinspiration were given in Tables-2 and 3.

For organic molecules, the probability is if the bioactivity scores $(>0)$, then it is active, if $(-5.0-0.0)$ then moderately active, if $(<-5.0)$ then inactive.

Osiris software: (https://www.Osiris.com) This software predicts the toxicity risk assessment and calculates on-the-fly various drug-relevant properties like cLogP, solubility, Molecular Weight, Toxicity Risk Assessment, Overall Drug-Score, etc. When the structure is valid Prediction results are valued and colorcoded like properties with a high risk of undesirable effect shown in red whereas green color indicates drugconform behavior.

\section{Results}

Table-1: General properties of Phyto-constituents of Bauhinia acuminata.

\begin{tabular}{|c|c|c|c|}
\hline $\begin{array}{l}\text { PHYTO- } \\
\text { CONSTITUENT }\end{array}$ & $\begin{array}{l}\text { MOLECUL } \\
\text { AR } \\
\text { FORMULA }\end{array}$ & SMILE NOTATION & STRUCTURE \\
\hline Quercetin & $\mathrm{C}_{15} \mathrm{H}_{10} \mathrm{O}_{7}$ & $\mathrm{C} 1=\mathrm{CC}(=\mathrm{C}(\mathrm{C}=\mathrm{C} 1 \mathrm{C} 2=\mathrm{C}(\mathrm{C}(=\mathrm{O}) \mathrm{C} 3=\mathrm{C}(\mathrm{C}=\mathrm{C}(\mathrm{C}=\mathrm{C} 3 \mathrm{O} 2) \mathrm{O}) \mathrm{O}) \mathrm{O}) \mathrm{O}) \mathrm{O}$ & \\
\hline Neophytadiene & $\mathrm{C}_{20} \mathrm{H}_{40}$ & $\mathrm{CC}(\mathrm{C}) \operatorname{CCCC}(\mathrm{C}) \operatorname{CCCC}(\mathrm{C}) \operatorname{CCCC}(=\mathrm{C}) \mathrm{C}=\mathrm{C}$ & \\
\hline Rhoeagenine & $\mathrm{C}_{19} \mathrm{H}_{17} \mathrm{NO}_{6}$ & $\begin{array}{c}\mathrm{CN} 1 \mathrm{CCC} 2=\mathrm{CC} 3=\mathrm{C}(\mathrm{C}=\mathrm{C} 2 \mathrm{C} 4 \mathrm{C} 1 \mathrm{C} 5=\mathrm{C}(\mathrm{C}(\mathrm{O} 4) \mathrm{O}) \mathrm{C} 6=\mathrm{C}(\mathrm{C}=\mathrm{C} 5) \mathrm{OCO}) \mathrm{O} \\
\mathrm{CO} 3\end{array}$ & \\
\hline Alpha humulene & $\mathrm{C}_{15} \mathrm{H}_{24}$ & $\mathrm{CC} 1=\mathrm{CCC}(\mathrm{C}=\mathrm{CCC}(=\mathrm{CCC} 1) \mathrm{C})(\mathrm{C}) \mathrm{C}$ & \\
\hline Isoaromadendrene epoxide & $\mathrm{C}_{15} \mathrm{H}_{24} \mathrm{O}$ & $\mathrm{CC} 1 \mathrm{CCC} 2 \mathrm{C} 1 \mathrm{C} 3 \mathrm{C}(\mathrm{C} 3(\mathrm{C}) \mathrm{C}) \mathrm{CC} 4 \mathrm{C} 2(\mathrm{O} 4) \mathrm{C}$ & \\
\hline $\begin{array}{l}\text { Butanedioic acid diethyl } \\
\text { ester }\end{array}$ & $\mathrm{C}_{8} \mathrm{H}_{14} \mathrm{O}_{4}$ & $\operatorname{CCOC}(=\mathrm{O}) \mathrm{CCC}(=\mathrm{O}) \mathrm{OCC}$ & \\
\hline $\begin{array}{l}9,12,15 \text {-octadecatrienoic } \\
\text { acid }\end{array}$ & $\mathrm{C}_{18} \mathrm{H}_{28} \mathrm{O}_{2}$ & $\mathrm{CCCCCC}=\mathrm{CCC}=\mathrm{CCCC}=\mathrm{CCCCC}(=\mathrm{O}) \mathrm{O}$ & \\
\hline Beta-ionone & $\mathrm{C}_{13} \mathrm{H}_{20} \mathrm{O}$ & $\mathrm{CC} 1=\mathrm{C}(\mathrm{C}(\mathrm{CCC} 1)(\mathrm{C}) \mathrm{C}) \mathrm{C}=\mathrm{CC}(=\mathrm{O}) \mathrm{C}$ & \\
\hline 9,12-octadecadienoic acid & $\mathrm{C}_{18} \mathrm{H}_{32} \mathrm{O}_{2}$ & $\mathrm{CCCCCC}=\mathrm{CCC}=\mathrm{CCCCCCCCC}(=\mathrm{O}) \mathrm{O}$ & \\
\hline
\end{tabular}




\begin{tabular}{|c|c|c|c|}
\hline Alpha muurolol & $\mathrm{C}_{15} \mathrm{H}_{26} \mathrm{O}$ & $\mathrm{CC} 1=\mathrm{CC} 2 \mathrm{C}(\mathrm{CCC}(\mathrm{C} 2 \mathrm{CC} 1)(\mathrm{C}) \mathrm{O}) \mathrm{C}(\mathrm{C}) \mathrm{C}$ & 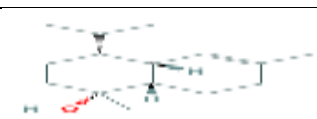 \\
\hline Bauhinione & $\mathrm{C}_{17} \mathrm{H}_{16} \mathrm{O}_{4}$ & $\mathrm{COC} 1=\mathrm{CC}=\mathrm{C} 2 \mathrm{C}(\mathrm{CCC} 3=\mathrm{C} 2 \mathrm{C}(=\mathrm{O}) \mathrm{C}(\mathrm{C})=\mathrm{C}(\mathrm{OC}) \mathrm{C} 3=\mathrm{O})=\mathrm{C} 1$ & \\
\hline Beta-sitosterol & $\mathrm{C}_{29} \mathrm{H}_{50} \mathrm{O}$ & $\begin{array}{c}\mathrm{CCC}(\mathrm{CCC}(\mathrm{C}) \mathrm{C} 1 \mathrm{CCC} 2 \mathrm{C} 1(\mathrm{CCC} 3 \mathrm{C} 2 \mathrm{CC}=\mathrm{C} 4 \mathrm{C} 3(\mathrm{CCC}(\mathrm{C} 4) \mathrm{O}) \mathrm{C}) \mathrm{C}) \mathrm{C}(\mathrm{C}) \\
\mathrm{C}\end{array}$ & \\
\hline Kaempferol-3-glucoside & $\mathrm{C}_{21} \mathrm{H}_{20} \mathrm{O}_{11}$ & $\begin{aligned} \mathrm{C} 1=\mathrm{CC}(=\mathrm{CC}=\mathrm{C} 1 \mathrm{C} 2=\mathrm{C}(\mathrm{C}(=\mathrm{O}) \mathrm{C} 3=\mathrm{C}(\mathrm{C}=\mathrm{C}(\mathrm{C}=\mathrm{C} 3 \mathrm{O} 2) \mathrm{O}) \mathrm{O}) \mathrm{OC} 4 \mathrm{C}(\mathrm{C}(\mathrm{C}( \\
\mathrm{C}(\mathrm{O} 4) \mathrm{C}(=\mathrm{O}) \mathrm{O}) \mathrm{O}) \mathrm{O}) \mathrm{O}) \mathrm{O}\end{aligned}$ & \\
\hline
\end{tabular}

Table-2: Computed molecular properties of the phytoconstituents present in Bauhinia acuminate.

\begin{tabular}{|c|c|c|c|c|c|c|c|c|c|}
\hline Phyto-constituent & Mi log p & TPSA & natoms & MW & nON & nOHNH & n violations & nrotb & volume \\
\hline Quercetin & 1.68 & 131.35 & 22 & 302.24 & 7 & 5 & 0 & 1 & 240.08 \\
\hline Neophytadiene & 7.55 & 0 & 20 & 278.52 & 0 & 0 & 1 & 13 & 336.04 \\
\hline Rhoeagenine & 2.34 & 69.64 & 27 & 369.37 & 7 & 1 & 0 & 0 & 312.06 \\
\hline Alpha humulene & 5.3 & 0 & 15 & 204.36 & 0 & 0 & 1 & 0 & 234 \\
\hline Isoaromadendrene epoxide & 4.27 & 12.53 & 16 & 220.36 & 1 & 0 & 0 & 0 & 228.88 \\
\hline Butanedioic acid diethyl ester & 0.71 & 52.61 & 12 & 174.2 & 4 & 0 & 0 & 7 & 168.9 \\
\hline $9,12,15$-octadecatrienoic acid & 6.37 & 37.3 & 20 & 278.44 & 2 & 1 & 1 & 13 & 306.47 \\
\hline Beta-ionone & 3.45 & 17.07 & 14 & 192.3 & 1 & 0 & 0 & 2 & 208.76 \\
\hline 9,12-octadecadienoic acid & 6.86 & 37.3 & 20 & 280.45 & 2 & 1 & 1 & 14 & 312.65 \\
\hline Alpha muurolol & 4.97 & 20.23 & 16 & 222.37 & 1 & 1 & 0 & 1 & 243.65 \\
\hline Bauhinione & 2.77 & 52.61 & 21 & 284.31 & 4 & 0 & 0 & 2 & 256.42 \\
\hline Beta-sitosterol & 8.62 & 20.23 & 30 & 414.72 & 1 & 1 & 1 & 6 & 456.52 \\
\hline Kaempferol-3-glucoside & 0.12 & 190.28 & 32 & 448.38 & 11 & 7 & 2 & 4 & 364.19 \\
\hline
\end{tabular}

Table-3: Computed Bioactivity scores of the Phyto-constituents of Bauhinia acuminata by Molinspiration

\begin{tabular}{|c|c|c|c|c|c|c|}
\hline PHYTO-CONSTITUENT & $\begin{array}{c}\text { GPCR } \\
\text { LIGAND }\end{array}$ & $\begin{array}{c}\text { ION CHANNEL } \\
\text { MODULATOR }\end{array}$ & $\begin{array}{c}\text { KINASE } \\
\text { INHIBITOR }\end{array}$ & $\begin{array}{c}\text { NUCLEAR } \\
\text { RECEPTOR } \\
\text { LIGAND }\end{array}$ & $\begin{array}{c}\text { PROTEASE } \\
\text { INHIBITOR }\end{array}$ & $\begin{array}{c}\text { ENZYME } \\
\text { INHIBITOR }\end{array}$ \\
\hline Quercetin & -0.06 & -0.19 & 0.28 & 0.36 & -0.25 & 0.28 \\
\hline Neophytadiene & -0.12 & -0.02 & -0.35 & 0.2 & -0.11 & 0.14 \\
\hline Rhoeagenine & 0.21 & 0.13 & -0.14 & -0.09 & 0.02 & 0.17 \\
\hline Alpha humulene & -0.14 & 0.02 & -0.93 & 0.34 & -0.67 & 0.31 \\
\hline Isoaromadendrene epoxide & -0.39 & -0.37 & -0.69 & -0.01 & 0.02 & -0.05 \\
\hline Butanedioic acid diethyl ester & -0.93 & -0.35 & -1.19 & -0.91 & -0.92 & -0.46 \\
\hline $9,12,15$-octadecatrienoic acid & 0.29 & 0.17 & -0.16 & 0.31 & 0.12 & 0.38 \\
\hline Beta-ionone & -0.9 & -0.26 & -1.34 & 0.25 & -0.79 & 0.28 \\
\hline 9,12 -octadecadienoic acid & 0.29 & 0.17 & -0.16 & 0.31 & 0.12 & 0.38 \\
\hline Alpha muurolol & -0.09 & 0.05 & -0.87 & 0.39 & -0.63 & 0.4 \\
\hline Bauhinione & -0.13 & -0.18 & 0.1 & 0.06 & -0.29 & 0.34 \\
\hline Beta-sitosterol & 0.14 & 0.04 & -0.51 & 0.73 & 0.07 & 0.51 \\
\hline Kaempferol-3-glucoside & 0.06 & -0.05 & 0.1 & 0.2 & -0.05 & 0.41 \\
\hline
\end{tabular}

Table-4: Computed Toxicity profile of the Phyto-constituents of Bauhinia acuminata by Osiris software 


\begin{tabular}{|c|c|c|c|c|c|c|c|c|c|}
\hline $\begin{array}{l}\text { PHYTO- } \\
\text { CONSTITUENTS }\end{array}$ & C LOG P & $\begin{array}{c}\text { DRUG } \\
\text { LIKENESS }\end{array}$ & $\begin{array}{l}\text { DRUG } \\
\text { SCORE }\end{array}$ & SOLUBILITY & TPSA & \begin{tabular}{|l} 
MUTAGE \\
NIC
\end{tabular} & $\begin{array}{l}\text { TUMORI } \\
\text { GENIC }\end{array}$ & $\begin{array}{l}\text { SKIN AND } \\
\text { EYE } \\
\text { IRRITANT }\end{array}$ & $\begin{array}{l}\text { REPRODU } \\
\text { CTIVE } \\
\text { EFFECT }\end{array}$ \\
\hline Quercetin & 1.49 & 1.6 & 0.3 & -2.49 & 127.4 & & & $\Gamma$ & \\
\hline Neophytadiene & 8.23 & -8.45 & 0.09 & -5.25 & 0 & E & & & \\
\hline Rhoeagenine & 2.61 & 4.8 & 0.79 & -3.61 & 69.62 & & & & \\
\hline Alpha humulene & 6.24 & -4.72 & 0.28 & -3.4 & 0 & & & [ & [ \\
\hline $\begin{array}{l}\text { Isoaromadendrene } \\
\text { epoxide }\end{array}$ & 2.9 & -3.29 & 0.16 & -3.52 & 12.53 & & & & \\
\hline $\begin{array}{ll}\begin{array}{l}\text { Butanedioic } \\
\text { diethyl ester }\end{array} & \text { acid } \\
\end{array}$ & 1 & -15.3 & 0.29 & -1.33 & 52.6 & & & & \\
\hline $\begin{array}{l}9,12,15- \\
\text { octadecatrienoic } \\
\text { acid }\end{array}$ & 6.21 & -19.1 & 0.25 & -4.09 & 37.3 & & & & \\
\hline Beta-ionone & 3.32 & -6.41 & 0.16 & -2.74 & 17.07 & & & & \\
\hline $\begin{array}{l}9,12- \\
\text { octadecadienoic acid }\end{array}$ & 6.47 & -25.5 & 0.24 & -4.32 & 37.3 & & & {[} & \\
\hline Alpha muurolol & 3.53 & -4.24 & 0.42 & -3.29 & 20.23 & & & & \\
\hline Bauhinione & 2.17 & 0.23 & 0.42 & -2.6 & 52.6 & & & & \\
\hline Beta-sitosterol & 7.86 & -4.48 & 0.13 & -6.67 & 20.23 & & & & \\
\hline $\begin{array}{l}\text { Kaempferol-3- } \\
\text { glucoside }\end{array}$ & 0 & -2.68 & 0.42 & -2.49 & 186.3 & & & & \\
\hline
\end{tabular}

\section{Discussion}

Table 1: General properties and structures of the phytoconstituents present in Bauhinia acuminata

Table 2 and 3: Molinspiration (molecular properties and Bioactivity scores)

\section{a) Molecular property of the phytochemical compounds}

Among the all the 13 phytochemical compounds screened for Insilco drug activity prediction which are done by molinspiration showed that all the phytochemical obeyed the Lipinski's rule of five and reflected good drug-likeness scores. The values of MiLog P for these compounds were found to be $<5$ indicating their good permeability across the cell membrane.

All the phytochemicals found to have molecular weight $<500$, TPSA well below $160 \AA ̊ 2$, Number of hydrogen bond donors $<5$, hydrogen bond acceptors $<4$, n-violations 0 , and number of rotatable flexible bonds $<5$, The observed data indicated that except Kaempferol-3-glucoside all the phytoconstituents were found to have drug-likeness property.

\section{b) Bioactivity scores of the compounds}

For organic molecules, the probability is if the bioactivity scores $(>0)$ then it is active, if $(-5.0-0.0)$ then moderately active, if $(<-5.0)$ then inactive.

The bioactivity scores of the 13 phytoconstituents observed were as follows:

\section{i) GPCR Ligand}

Rhoeagenine, 9, 12-octadecadienoic acid, Beta-sitosterol, Kaempferol-3-glucoside are showing good GPCR binding activity

\section{ii) Ion channel modulator}

Rhoeagenine, Alpha humulene, 9, 12, 15-octadecatrienoic acid, 9, 12-octadecadienoic acid, Alpha muurolol, Beta-sitosterol are showing good ion channel modulator activity.

\section{iii) Kinase inhibitor}


Quercetin, Bauhinione, Kaempferol-3-glucoside are having good Kinase Inhibitor activity

iv) Nuclear receptor Ligand

Rhoeagenine, Isoaromadendrene epoxide, Butanedioic acid diethyl ester all the other Phytoconstituents are showing good Nuclear receptor binding activity

\section{v) Protease inhibitor}

Rhoeagenine, Isoaromadendrene epoxide, 9, 12, 15-octadecatrienoic acid, 9, 12-octadecadienoic acid, Betasitosterol are showing good Protease inhibitor activity.

\section{vi) Enzyme inhibitor}

Except for Isoaromadendrene epoxide, Butanedioic acid diethyl ester all the phytoconstituents are showing good enzyme binding activity.

Rhoeagenine, 9, 12, 15-octadecatrienoic acid, and 9, 12-octadecadienoic acid are the phytoconstituents showing all types of binding with all types of receptors except Kinase inhibitor activity.

\section{Table 4: Osiris (Toxicity prediction)}

Zero and positive values indicate good drug score and drug likeliness. Drug score and drug likeliness are good for Rhoeagenine

Mutagenicity: Quercetin showing Mutagenicity

Tumorogenicity: Quercetin, Isoaromadendrene epoxide, Beta-ionone are showing tumorogenicity

Skin and eye Irritation: Isoaromadendrene epoxide, Beta-ionone, Butanedioic acid diethyl ester are showing skin and Eye Irritation

Reproductive effects: Beta-sitosterol is showing Reproductive effects.

Rhoeagenine, Alpha humulene, 9, 12, 15-octadecatrienoic acid, 9,12-octadecadienoic acid, Alpha muurolol, Beta-sitosterol, Kaempferol-3-glucoside are the phytoconstituents that are free from any type of toxicity.

\section{Conclusion}

In the present study, we used Molinspiration, Osiris online software tool which is available free for the users to evaluate the molecular properties, bioactivity scores, toxicity predictions of the phytoconstituents present in Bauhinia acuminata. The phytoconstituents of the plants were enlisted through the software includes Quercetin, Neophytadiene, Rhoeagenine, Alpha humulene, Butanedioic acid diethyl ester, 9,12,15octadecatrienoic acid, Beta-ionone, 9,12-octadecadienoic acid, Alpha muurolol, Bauhinione, Kaempferol3 -glucoside. Accordingly, the respective software data for the phytoconstituents are computed and depicted in respective tables. Further, these values can be used as monographs by researchers and scientists for the development of potential Semisynthetic and synthetic drugs for multifarious usage.

\section{Acknowledgement}

"Not applicable".

\section{Conflicts of Interest}

There are no conflicts of interest.

\section{References}

1. Khan MF, Shilpi RI, Rashid R, Rashid MA (2014). In vitro antioxidant, cytotoxic and membrane stabilizing activities of L. Bangladesh Bauhinia acuminata. Pharmaceutical Journal, 17(1): 99-101. In vitro Antioxidant, Cytotoxic and Membrane Stabilizing Activities of Bauhinia acuminata L. Mohammad Firoz Khan - Academia.edu

2. Phansri K, Sarnthima R, Thammasirirak S, Boonchalee P, Khammuang S (2011). Antibacterial activity of Bauhiniaacuminata L. seed protein extract with low hemolytic activity against human erythrocytes. Chiang Mai Journal of Science, 38(2):242-251. 
https://www.thaiscience.info/Journals/Article/CMJS/10905420.pdf

3. Padgaonkar AV, Suryavanshi SV, Londhe VY, Kulkarni YA (2018). Acute toxicity study and antinociceptive activity of Bauhinia acuminata Linn leaf extracts in experimental animal models. Biomedicine and Pharmacotherapy, 2(7):158-168.

Acute toxicity study and anti-nociceptive activity of Bauhinia acuminata Linn. leaf extracts in experimental animal models - PubMed (nih.gov)

4. Islam M, Fahad M, Hossain M, Mamun M, Ferdous M (2014). In-vitro Cytotoxic and thrombolytic activity of methanolic extraction of Bauhinia acuminata leaves. Pharmaceutical and Bioscience, 2(2):4-6.

(PDF) In-vitro Cytotoxic and Thrombolytic Activity of Methanolic Extract of Bauhinia acuminata Leaves | Md.Reyad ferdous - Academia.edu

5. Khan MF, Shilpi RI, Rashid R, Rashid M (2014). In vitro antioxidant, cytotoxic and membrane stabilizing activities of Bauhinia acuminata L. Bangladesh Pharmaceutical Journal, 17(1):99-101.

In vitro Antioxidant, Cytotoxic and Membrane Stabilizing Activities of Bauhinia acuminata L. Mohammad Firoz Khan - Academia.edu

6. Prabhu R, Razali N, Dhandapani N, Nagaraj P, Muthaiyan P, Joseph JR (2018). In Vitro Anthelmintic Study of Bauhinia Acuminata Linn. Leaf Extracts against the Indo American Journal of Pharmaceutical Sciences, 05(06):5082-5089.

\section{www.stuartxchange.org/Bambang.html}

7. Islam MN, Fahad AB (2014). In-vivo Antidiarrheal and In-vitro Antimicrobial Activities of the Leaf Extracts of Bauhinia acuminata. American Journal of Research Communication, 2(7):158-168.

Islam_Vol27.pdf (usa-journals.com)

8. Ravali P, Challa PK, Soundarya V (2015). Hepatoprotective activity of ethanolic Bauhinia acuminata. L Extract against CCI4-Induced liver damage in rat. Pharma Research Library, 8:8-12.

IJMPR3719.pdf (pharmaresearchlibrary.com)

9. Yi F (2016). In silico profiling for secondary metabolites from Lepidium meyenii(maca) by the pharmacophore and ligand-shape-based joint approach. Chin Med, 11(1):42.

In silico profiling for secondary metabolites from Lepidium meyenii (maca) by the pharmacophore and ligand-shape-based joint approach (biomedcentral.com)

10. Dongray R, Chanchal D, Chaudhary S (2016). Phytochemical and Pharmacological Properties of Bauhinia Acuminata. World Journal of Pharmaceutical Research, 5(01):531-546.

https://www.semanticscholar.org/paper/PHYTOCHEMICAL-AND-PHARMACOLOGICALPROPERTIES-OF-DongrayIrchhaiya/14a2c30c7640523f61778fc5c47b81f80756e1fc

11. Sharma. S.K (2010). Green Chemistry for Environmental Sustainability. Series: Advancing Sustainability through Green Chemistry and Engineering. CRC Press, Boca Raton, FL. Green chemistry for environmental sustainability | Sanjay K. Sharma, Ackmez Mudhoo (editors)| download (b-ok.global) 